\title{
The Production Of Biodegradable Fuel From Nonedible Oilseed In India: A Review
}

\author{
Brajesh Kumar Mishra and Dr. Rajat Kumar \\ Dept. of Chemistry, Singhania University, jhunjhunu Rajasthan
}

\begin{abstract}
As the stock of fossil fuels are decreasing throughout the world and demands for energy based Comforts and mobility ever increasing, so there is a need to increase biodiesel production. Bio diesel is an alternative diesel fuel prepared from renewable resources and is most popular as an alternative energy sources because it is non toxic and biodegradable. India has great potential for production of biodiesel from non-edible oil seeds. From about 100 varieties of oil seeds, only 10-12 varieties have been tapped so far. The promising non-edible sources in India are Madhuca Indica (Mahua),Jatropha curcas(Ratan Jyot), Pongamia and pinnata (Karanja). This review paper assesses and integrates the biological, chemical and genetic attributes of the plant and describes about the different tree borne oilseeds in India,
\end{abstract}

Keywords: Tree borne oil seeds, Non edible oils, transesterification, and Bio diesel.

\section{INTRODUCTION}

Biofuels are being given serious consideration as potential sources of energy in the future, particularly in developing countries like India. Due to recent petroleum crisis[1-2] and unavailability of petroleum diesel the demand for petroleum diesel is increasing day by day hence there is a need to find out an appropriate solution. Biodiesel is a clean burning alternate fuel, both edible and non-edible. It can be used in compression-ignition (diesel) engines with little or no modifications.Bio diesel is simple to use, biodegradable, nontoxic, and essentially free of sulfur and aromatics. It can be stored just like petroleum diesel fuel and hence does not require a separate infrastructure. The use of biodiesel in conventional diesel engines results in substantial reduction of unburned hydrocarbons, carbon monoxide and particulate matters. Its higher cetane number improves the ignition quality even when blended in petroleum diesel.Indian plants like Jatropha (Jatropha curcas), Mahua (Madhuca Indica ) and Karanja (Pongamia pinnata) contain 30\% or more oil in their seed,fruite or nut. In india edible oil in short supply, non-edible tree borne oilseeds (TBOs) of karanja, Jatropha and Mahua considered as the source of straight vegetable oil (SVO) and biodiesel. Plant species, which have $30 \%$ or more fixed oil in their seeds or kernel, have been identified [3].There are many ways and procedures to convert vegetable oil into a Diesel like fuel, the trans-esterification process was found to be the most viable process [4]. Trans-esterified oils have proven to be a viable alternative diesel engine fuel with characteristics similar to those of Diesel fuel. Its physical and chemical properties required for operation of diesel engine are similar to petroleum based diesel fuel. [5] Just like petroleum diesel, biodiesel operates in compression-ignition engines.Transesterification is a chemical reaction that aims at substituting the glycerol of the glycerides with three molecules of monoalcohols such as Methanol thus leading to three molecules of methyl ester of vegetable oil [6]. Methanol and ethanol is widely used in the transesterification .Methanol is used because of low cost, and physicochemical advantages with triglycerides and sodium hydroxide [7].The acid catalyst is the choice for transesterification when Low-grade vegetable oil used as raw material because it contains high free fatty acid (FFA) and moisture. Acid catalyst as sulphuric acid $\left(\mathrm{H}_{2} \mathrm{SO}_{4}\right)$ is used for esterification process.

\section{Major non-edible tree borne oilseeds (TBOs)}

\section{MATERIALS AND METHODS}

\section{1. i. Mahua (Madhuca Indica)}

Bio diesel from mahua seed is important because most of the states of India are tribal where it is found abundantly.The annual production of mahua is nearly $181 \mathrm{Kt}$. Mahua is a nontraditional, non-edible oil also known as Indian butter tree. Mahua seed contain 30-40 percent fatty oil called mahua oil[8-13]. It can be sucessesfully grown in waste land \& dry land. The tree has potential of enhancing rural income. Mature seeds can be obtained during June to July. Seed yield ranges from $20-200 \mathrm{~kg}$ per tree every year, depending on its growth and development. Mahua flowers are rich in sugar, minerals, vitamins and calcium. The fatty acid composition of mahua oil oil has been reported in Table - 1[14]. 


\section{1.ii. Jatropha (Jatropha curcas)}

Jatropha curcus is a drought-resistant perennial, growing well in marginal/poor soil. Jatropha the wonder plant produces seeds with an oil content of around 37\%. The oil can be combusted as fuel without being refined. It burns with clear smoke-free flame, tested successfully as fuel for simple diesel engine. The byproducts are press cake a good organic fertilizer, oil contains also insecticide. J.curcas grows almost anywhere, even on gravelly, sandy and saline soils. It can thrive on the poorest stony soil. Its water requirement is extremely low and it can stand long periods of drought by shedding most of its leaves to reduce transpiration loss. Jatropha is also suitable for preventing soil erosion and shifting of sand dunes. The fatty acid composition of jatropha oil has been reported in Table - 2[14].

\section{1. iii. Karanja (Pongamia pinnata)}

Karanja is a medium sized tree is found almost throughout India. Karanja tree is wonderful tree almost like neem tree. The common name of the oil is Karanja Seed Oil and the botanical name is Pongamia glabra of Leguminaceae family. Pongamia is widely distributed in tropical Asia and it is nonedible oil of Indian origin . The plant is also said to be highly tolerant to salinity and can be grown in various soil textures viz. stony, sandy and clayey. Karanja can grow in humid as well as subtropical environments. The tree bears green pods which after some 10 months change to a tan colour. The pods are flat to elliptic, $5-7 \mathrm{~cm}$ long and contain 1 or 2 kidney shaped brownish red kernels. The yield of kernels per tree is reported between 8 and $24 \mathrm{~kg}$. The kernels are white and covered by a thin reddish skin. The composition of typical air dried kernels is: Moisture 19\%, Oil $27.5 \%$, and Protein $17.4 \%$. The present production of karanja oil approximately is 200 million tons per annum. The time needed by the tree to mature ranges from 4 to 7 years and depending on the size of the tree the yield of kernels per tree is between 8 and $24 \mathrm{~kg}$. The oil content extracted by various authors ranges between 30.0 to $33 \%$ [3]. The oil is used by common people due to its low cost and easy availability. The fatty acid composition of karanja oil has been reported in Table -3[14].

\section{Oil processing technology of oil seeds}

\section{2. i. Oil extraction and Purification of Oil}

Although oil extraction can be done with or without seed coat, for jatropha, utilization of a Mechanical dehulling system (to remove the seed coat) can increase oil yield by $10 \%$. While in cold pressing $\left(<60^{\circ} \mathrm{C}\right)$, around $86-88 \%$ efficiency is achieved, hot pressing $\left(110-120^{\circ} \mathrm{C}\right)$ can increase it to around $90 \%$. This necessitates a further step of oil de gumming before trans-esterification. Oil extraction methods are also being developed based on fermentation hydrolysis. In this process, cell walls of the oil plant seeds are destroyed followed by the release of the oil present within the cells [15]. This new method not only produces higher quality of oil and cake but also requires much less energy and results in lower levels of environmental pollution. The extracted oil can be purified by Sedimentation prosesss. This is the easiest way to get clear oil, but it takes about a week until the sediment is reduced to $20-25 \%$ of the raw oil volume.The purification process can be accelerated tremendously by boiling the oil with about $20 \%$ of water.

\section{2. ii. Detoxification of seed cake}

After extraction of oil from seed the detoxification of the seed cake is necessary so that the seed cake can be used as cattle feed. From Several investigations it is found that de-acidification and bleaching could reduce the content of toxic phorbol esters to $55 \%$ [16].

\section{Biodiesel processing}

There are four ways in which oils and fats can be converted into biodiesel, namely, Transesterification, micro emulsions and paralysis. The process of converting the raw vegetable oil into biodiesel, which is fatty acid alkyl ester, is termed as transesterification. There are three basic routes to biodiesel production from oil are such as base catalyzed transesterification of the oil, direct acid catalyzed transesterification of the biolipid and Conversion of the biolipid to its fatty acids and then to biodiesel.transesterification being the most commonly used method. Conversion is complicated if oil contains higher amounts of FFA (>1\% w/w) that will form soap with alkaline catalyst. The soap can prevent separation of the biodiesel from the glycerin fraction. Crude oil contains about more than $25 \%$ FFA, which is far beyond the $1 \%$ level. The reduction of FFA $<1 \%$ is best if esterification followed by Trans-esterification.

\section{3. i. Esterification}

Normally most of the oils are converted into biodiesel ester using the base catalysed trans-esterifcation method. If nonedible oil posses high free fatty acid and acid value $>3$ then Trans -esterification followed by esteri fication. 


\section{3. ii. Transesterification}

Transesterification also called alcoholysis is the displacement of alcohol from an ester by another alcohol in a process similar to hydrolysis, except that an alcohol is employed instead of water. Methanol and ethanol are utilized most frequently. This process is widely used to reduce the viscosity of triglycerides, thereby enhancing the physical properties of fuel and improve engine performance. Thus fatty acid methyl ester (also known as biodiesel) is obtained by transesterification. The yields of methyl ester are maximum (85-90\%) if trans esterification carried out in mechanical stirrer which has 1100 revolutions per minuts (rpm).

Table 1. Fatty acid profile of mahua oil [8]

\begin{tabular}{|l|l|l|l|}
\hline Fatty Acid & Formula & Structure & Wt\% \\
\hline Palmitic & $\mathrm{C}_{16} \mathrm{H}_{32} \mathrm{O}_{2}$ & $16: 0$ & $16.0-28.2$ \\
\hline Stearic & $\mathrm{C}_{18} \mathrm{H}_{36} \mathrm{O}_{2}$ & $18: 0$ & 20.25 .1 \\
\hline Arachidic & $\mathrm{C}_{20} \mathrm{H}_{40} \mathrm{O}_{2}$ & $20: 0$ & $0.0-3.3$ \\
\hline Oleic & $\mathrm{C}_{18} \mathrm{H}_{34} \mathrm{O}_{2}$ & $18: 1$ & $41.0-51.0$ \\
\hline Linoleic & $\mathrm{C}_{18} \mathrm{H}_{32} \mathrm{O}_{2}$ & $18: 2$ & $8.9-13.7$ \\
\hline
\end{tabular}

Table 2. Fatty acid profile of jatropha oil [14]

\begin{tabular}{|l|l|l|l|}
\hline Fatty Acid & Formula & structure & Wt\% \\
\hline Myristic & $\mathrm{C}_{12} \mathrm{H}_{28} \mathrm{O}_{2}$ & $14: 0$ & $0.5-1.4$ \\
\hline Palmitic & $\mathrm{C}_{16} \mathrm{H}_{32} \mathrm{O}_{2}$ & $16: 0$ & $12-7.0$ \\
\hline Stearic & $\mathrm{C}_{18} \mathrm{H}_{36} \mathrm{O}_{2}$ & $18: 0$ & $5.0-9.7$ \\
\hline Oleic & $\mathrm{C}_{18} \mathrm{H}_{34} \mathrm{O}_{2}$ & $18: 1$ & $37-63$ \\
\hline Linoleic & $\mathrm{C}_{18} \mathrm{H}_{32} \mathrm{O}_{2}$ & $18: 2$ & $19-41$ \\
\hline
\end{tabular}

Table 3. Fatty acid profile of Karanja oil [14]

\begin{tabular}{|c|l|l|l|}
\hline Fatty Acid & Formula & structure & Wt\% \\
\hline Palmitic & $\mathrm{C}_{16} \mathrm{H}_{32} \mathrm{O}_{2}$ & $16: 0$ & $3.7-7.9$ \\
\hline Stearic & $\mathrm{C}_{18} \mathrm{H}_{36} \mathrm{O}_{2}$ & $18: 0$ & $2.4-8.9$ \\
\hline Lignoceric & $\mathrm{C}_{20} \mathrm{H}_{40} \mathrm{O}_{2}$ & $24: 0$ & $1.1-3.5$ \\
\hline Oleic & $\mathrm{C}_{18} \mathrm{H}_{34} \mathrm{O}_{2}$ & $18: 1$ & $44.5-71.3$ \\
\hline \multicolumn{1}{|c|}{ Linoleic } & $\mathrm{C}_{18} \mathrm{H}_{32} \mathrm{O}_{2}$ & $18: 2$ & $10.8-18.3$ \\
\hline
\end{tabular}

\section{RESULT AND DISCUSSION}

Maximum production of biodiesel is occurs at atmospheric pressure and 60-8000c temperature in the molar ratio of 6:1. Biodiesel is highly biodegradable in freshwater as well as soil environments. 90-98\% of biodiesel is mineralized in 21-28 days under aerobic as well as anaerobic conditions [17-19]. It is preferable to store the fuel in clean, dry and dark environment. However the stability can be increased by doping with antioxidants. Biodiesel has poor oxidation stability.

India has great potential for production of nonedible oilseed in 10-12 varieties. The annual estimated potential is about 21 million tones. As survey of Government of India, about 175 million hectares land are classified as waste and degraded. It is required to select and evolve quick growing and highly yield varieties of 
plants for various regions in india. At the national level it is required to set up a very effective task force the coordination of plantation, production, distribution and marketing activities.

\section{CONCLUSION}

Edible oils are in use in developed nations such as USA and European nations but in developing countries the production of edible oils are not sufficient. In a country like India, there are many plant species whose seeds remain unutilized and underutilized have been tried for biodiesel production. Non-edible oil seeds are the potential feedstock for production of biodiesel in India.These species have shown promises and fulfills various biodiesel standards. India, with its huge waste/non-fertile lands, has taken a well noted lead in the area and commercial production. Proper processing of non-edible oil seeds and transesterification can ascertain the quality of biodiesel and can be fulfill the large commercial application.

\section{ACKNOWLEDGEMENT}

Sincere thanks to Dr. Rajat Kumar, Associate Proff. D.A.V P.G College Kanpur for his useful suggestion and encouragement.

\section{REFERENCES}

[1] N.S.Venkataraman, Chemical Industry Digest,pp.77(2004)

[2] Based Biodiesel-Opportunities and contents in developing countries like India, Chemical Industries News, (2004) p,p.79

[3] Azam A. M., and Nahar N. M., 2005. Biomass and Bioenergy. 2005 Article in Press.

[4] Ma F, Hanna MA. Biores Technol 1999;70: 1-15.

[5] Srivastava, A and Prasad, R, Oil Energy 2000; Rev.4:111-133

[6] Sihna S, Bhardwaj D, Gupta PK, Biomass and Bio energy. 2004 ; 13:501-505.

[7] Pramanik K, Srivani K, Chandra V, Indian chemical engineering congress. 2000;

[8] Altin R, Cetinkaya S, Yucesu HS. Energy Convers Manage 2001;42: 529-38.

[9] Agarwal AK, Das LM, Journal of engineering for For Turbines and power. 2001; 123:440- 447.

[10] Ram BVB, Ramanathan V, Phuan S, Vedaraman N, Indian chemical Engg. Journal. 2004; 14(2):12-15.

[11] Phuan S, Vedaraman N, Sankaranarayanan G, Ram BVB, Renewable energy. 2005; 30:1269-1278.

[12] Azam MM, Waris A, Nahar NM. Biomass and Bioenergy. 2005; 29: 293-302.

[13] Carraretto C, Macor A, Mirandola A, Stoppato A, Tonon S, Energy. 2004; 29:2195-2211.

[14] Katwal RPS, Soni PL. Indian Forester 2003;129(8):939-49

[15] Janulis, P. Renewable energy, 2004; 29: $861-871$.

[16] Haas, W., Mittelbach, M. Industrial crops and products, 2000;12 (2): 111- 118.

[17] Pasqualino JC, Montane D, Salvado J. Biomass Bioenergy 2006;30:874-9.

[18] Zhang X, Peterson C, Reece D, Moller G, Haws R. Trans Am Soc Agric Eng 1998;41:1423-30.

[19] Makareviciene V, Janulis P. Renew Energy 2003;28(15):2395-403. 